\title{
Effects of Different Biochars on Physicochemical Properties and Fungal Communities of Black Soil
}

\author{
Yan Du ${ }^{1,2}$, Junnan Wu ${ }^{1,2}$, Paul-Simon Anane ${ }^{1,2}$, Yangsheng $\mathrm{Wu}^{1,2}$, \\ Chengyu Wang ${ }^{1,2}$, Shuxia Liu ${ }^{1,2 *}$ \\ ${ }^{1}$ College of Resource and Environmental Science, Jilin Agricultural University, Changchun, China \\ ${ }^{2}$ Key Laboratory of Soil Resource Sustainable Utilization for Jilin Province Commodity Grain Bases, \\ Changchun, China
}

Received: 6 May 2018

Accepted: 3 September 2018

\begin{abstract}
In this study, a combination of indoor culture and high-throughput sequencing was used to analyze changes in nutrients and fungal communities in black soil after the addition of biomass charcoal. The following conclusions were drawn: 1) After six months of constant temperature, black soils containing biomass carbon changed in physicochemical properties. For example, soil pH, organic matter, water content, available phosphorus, and available potassium increased compared with CK treatment $(\mathrm{P}<0.05)$. 2) It was observed from high-throughput sequencing that the fungal diversity of black soil also changed. High-throughput sequencing detected five fungal phyla, including Ascomycota, Basidiomycota, Chytridiomycota, Zygomycota, and Aspergillus (Glomeromycota), in which Ascomycota was the predominant group of fungi, which accounted for about $70.6 \%$ of the total number of OTUs. The sequencing also detected 67 known genera, among which the dominant genus included the genus Geomyces and sickle Fusarium, Chaetomium, Penicillium, Humicola. The analysis of fungal diversity concluded that the abundance and diversity of fungi in the black soil after adding biomass carbon increased. In the redundancy analysis (RDA), environmental factors had a great influence on the abundance and community composition of fungi. Therefore, adding biomass carbon could not only improve the soil nutrients but also were significant in maintaining the diversity of soil fungal communities.
\end{abstract}

Keywords: biochar, black soil, high-throughput sequencing, fungal diversity

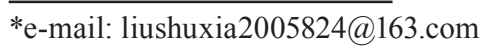




\section{Introduction}

Biochar is a solid product produced by the process of pyrolysis at high temperature. This product has existed for thousands of years, and charcoal is the most common type of life. The application of biomass carbon is also very common, such as thermoelectric production, metallurgical applications and agriculture and animal husbandry, etc. [1]. Biomass carbon in agriculture is considered by many scholars as a soil conditioner and a possible means to mitigate climate change [2]. Biochar has characteristics such as high $\mathrm{pH}$ value, high surface area and high $\mathrm{C} / \mathrm{N}$ ratio [3]. The way that biomass charcoal changes soil fertility is mainly through changing the $\mathrm{pH}$ of acidic soil [4] or by changing the adsorption capacity of cations and improving soil nutrients [5]. Hence, biochar is considered to be a good soil conditioner [6]. Many studies have also shown that biomass charcoal can change the composition and abundance of soil biomes [7]. This may change nutrient cycling [8] and soil structure [9], thus promoting plant growth [10]. For example, a soil rich in biomass carbon in the Amazon region has been found to significantly increase the number of microbes in soil [11]. Early studies on biomass charcoal focused on improving crop yields. For example, in 1994 Japan used biomass charcoal to increase citrus yield [12]. As biomass charcoal is increasingly known by people, the role of biochar has been transformed into soil improvement. Some studies have shown that biochar-added soils can increase microbial biomass. In recent years, most scholars have begun studying the biochar on the species richness and abundance of soil microorganisms [13]. H.Tong et al. [14] showed that adding biomass charcoal to paddy soil can increase the number of bacteria and will enhance the abundance of functional microorganisms for PCP transformation in soils. Most studies have also pointed out that the proper application of biomass carbon can regulate soil microbial community structure.

There are great differences in the properties of different biomass charcoal, such as its own nutrient content and $\mathrm{pH}$, and there are also great differences in their chemical and physical properties [15-17]. Biochar has been discovered and applied in agricultural production practice because of its unique properties. However, most scholars have only studied the effect of biomass carbon on soil microbial communities. This is a call for the need to research further its effects on soil microbes. Therefore, in this paper, we tested the effects that black soil with and without three different types of biomass charcoal have on the soil fungal community and soil nutrients.

\section{Materials and Methods}

\author{
Test Soil and Biochar
}

\section{Test Soil}

The test soil was a typical black soil and was collected from the long-term location test points $\left(43^{\circ} 47^{\prime} 42^{\prime \prime} \mathrm{N}, 1^{\circ} 3^{\circ} 20^{\prime} 45^{\prime \prime} \mathrm{E}\right)$ of Jilin Agricultural University. Corn is the major crop mostly cultivated on this soil. The fertilizers applied mostly during corn production are $\mathrm{N} 180 \mathrm{~kg} \mathrm{hm}^{-2}$ and $\mathrm{P}_{2} 0_{5} 90 \mathrm{~kg} \mathrm{hm}^{-2}, \mathrm{~K}_{2} 0$ $90 \mathrm{~kg} \mathrm{hm}^{-2}$, soil bulk density of $1.15 \mathrm{~g} \mathrm{~cm}^{-3}$. The soil sample was collected from the $0-20 \mathrm{~cm}$ plow layer soil, and after air drying, it was sieved by $2 \mathrm{~mm}$. The basic physicochemical traits are shown in Table 1.

\section{Test Biochar}

Three kinds of biomass carbon were provided by Dalian Xinglongxi Development Co., Ltd.: corn stover, rice husk, and pine wood pyrolyzed at $350-550^{\circ} \mathrm{C}$. The basic physical and chemical properties of biomass carbon are shown in Table 2.

\section{Training Test Design}

Bio-char-soil preparation: black soil over $2 \mathrm{~mm}$ sieve and biomass charcoal over 20 mesh sieve were initially obtained. The air-dried black soil sample was mixed with certain quantities of each biomass charcoal to obtain $1000 \mathrm{~g}$ for each treatment. A total of 7 treatments were included in the trial: 1) only black soil (CK); 2) black soil $+1.2 \%$ corn stover biomass carbon (CB); 3 ) black soil $+6.0 \%$ corn stover biomass carbon $(\mathrm{CB}) ; 4$ ) black soil $+1.2 \%$ rice husk biomass charcoal (RB); 5 ) black soil $+6.0 \%$ rice husk biomass charcoal (RB); 6 ) black soil $+1.2 \%$ pine biomass carbon (PB); and 7) black soil $+6.0 \%$ pine wood Biochar $(\mathrm{PB})$. Treatments were put in plastic bowls and randomly placed in an incubator at constant temperature and humidity. Samples were incubated at $25^{\circ} \mathrm{C}$ for 6 months and moisture was always adjusted to $70 \%$ of field capacity. We had three repeats per treatment (Note: $1.2 \%$ is $1.2 \%$ of total weight; $6.0 \%$ is $6.0 \%$ of full weight).

\section{Research Methods}

\section{Sampling of Mixed Culture Soil}

After the biomass carbon-black soil mixed treatments were cultured for six months, two soil samples were

Table 1. Physicochemical characteristics of the test soil.

\begin{tabular}{|c|c|c|c|c|c|c|c|}
\hline $\mathrm{pH}$ & $\begin{array}{c}\mathrm{SOM} \\
\left(\mathrm{g} \cdot \mathrm{kg}^{-1}\right)\end{array}$ & $\begin{array}{c}\mathrm{AN} \\
\left(\mathrm{mg} \cdot \mathrm{kg}^{-1}\right)\end{array}$ & $\begin{array}{c}\mathrm{AP} \\
\left(\mathrm{mg} \cdot \mathrm{kg}^{-1}\right)\end{array}$ & $\begin{array}{c}\mathrm{AK} \\
\left(\mathrm{mg} \cdot \mathrm{kg}^{-1}\right)\end{array}$ & $\begin{array}{c}\text { Clay } \\
(\%)\end{array}$ & $\begin{array}{c}\text { Silt } \\
(\%)\end{array}$ & $\begin{array}{c}\text { Sand } \\
(\%)\end{array}$ \\
\hline 5.55 & 21.52 & 84.25 & 15.68 & 192.05 & 34.75 & 25.47 & 39.77 \\
\hline
\end{tabular}


Table 2. Physicochemical characteristics of the test biochars.

\begin{tabular}{|c|c|c|c|}
\hline Measurement items & $\mathrm{CB}$ & $\mathrm{RB}$ & $\mathrm{PB}$ \\
\hline Ash $(\%)$ & $41.61 \pm 1.2$ & $38.62 \pm 2.1$ & $8.08 \pm 0.8$ \\
\hline $\mathrm{pH}\left(\mathrm{H}_{2} \mathrm{O}\right)$ & $9.82 \pm 0.6$ & $8.48 \pm 0.5$ & 97.20 \\
\hline Specific surface area $\left(\mathrm{m}^{2} \cdot \mathrm{g}^{-1}\right)$ & 4.05 & 8.20 & $210.20 \pm 1.4$ \\
\hline Organic carbon $\left(\mathrm{g} \cdot \mathrm{kg}^{-1}\right)$ & $463.54 \pm 1.6$ & $708.50 \pm 2.5$ & $11.07 \pm 1.7$ \\
\hline Total phosphorus $\left(\mathrm{g} \cdot \mathrm{kg}^{-1}\right)$ & $16.20 \pm 1.1$ & $13.16 \pm 1.4$ & $5.01 \pm 1.8$ \\
\hline $\mathrm{AP}\left(\mathrm{mg} \cdot \mathrm{kg}^{-1}\right)$ & $219.97 \pm 2.2$ & $385.28 \pm 2.1$ & 80.04 \\
\hline $\mathrm{C}(\%)$ & 49.62 & 44.88 & 1.72 \\
\hline $\mathrm{H}(\%)$ & 4.68 & 2.04 & 0.39 \\
\hline $\mathrm{N}(\%)$ & 1.37 & 1.33 & 17.63 \\
\hline $\mathrm{O}(\%)$ & 43.80 & 51.40 & 0.22 \\
\hline $\mathrm{S}(\%)$ & 0.53 & 0.35 & \\
\hline
\end{tabular}

taken from each treatment. One for DNA extraction and the other for basic data determination. The soil was passed over $2 \mathrm{~mm}$ sieve for the removal of impurities. The same treatment was mixed three times in parallel. Samples for DNA extraction were stored at $-80^{\circ} \mathrm{C}$ and samples for basic data determination were air dried.

\section{Determining Basic Data}

Soil $\mathrm{pH}$, organic matter, total nitrogen, total phosphorus, alkali-hydrolyzable nitrogen, available phosphorus, available potassium, and soil water content were measured according to soil agrochemical analysis [18].

\section{Extraction and Detection of Total Soil DNA}

Soil microbial DNA extraction was performed using the Power Soil DNA Isolation Kit from MOBIO, USA. $0.5000 \mathrm{~g}$ of soil samples were weighed and stored in a refrigerator at $-80^{\circ} \mathrm{C}$ in order to extract total DNA and purify soil genomic DNA (TIAN quick Midi Purification Kit, TIANGEN) according to the kit manual procedure; detected by ultra-micro spectrophotometer (Nanodrop 2000) DNA concentration $\geq 20 \mathrm{ng} \cdot \mu \mathrm{L}^{-1}, \mathrm{OD}_{260 / 280}$ between 1.8 and 2.0, and $\mathrm{OD}_{260 / 230}$ between 1.8 and 2.0. The extracted DNA was stored at $-20^{\circ} \mathrm{C}$ for subsequent measurement.

\section{High-throughput Sequencing of the Illumina} MiSeq Platform

The construction of a high-throughput sequencing library was completed by GENEWIZ Corporation (Suzhou, China). The ITS2 variable region of the fungal ITS rDNA was amplified by PCR using 5 to $50 \mathrm{mg}$ of DNA as a template. The end of the PCR product of the ITS rDNA was labeled by PCR with a linker Index.
The library quality was detected using an Agilent 2100 Bioanalyzer (Agilent Technologies, Palo Alto, CA, USA) and the library concentration was detected by Qubit and real-time quantitative PCR (Applied Biosystems, Carlsbad, CA, USA). After the DNA library was mixed, double-ended sequencing (PE) was performed using the Illumina MiSeq (Illumina, San Diego, CA, USA) instrument instruction manual. Image analysis and base-calling were performed using the MiSeq Control Software (MCS) in the MiSeq tool. Finally, an initial classification analysis was performed on the Illumina base space cloud computing platform.

All sequences were deposited in the NCBI sequence read archive (SRA) database (accession Nos. SRR7174967-SRR7174973).

\section{Data Processing}

OTU analysis uses V-SEARCH (1.9.6) for sequence clustering (sequence similarity is set to $97 \%$ ), and the aligned ITS rDNA reference database is UNITE ITS database (https://unite.ut.ee/), and then RDP is used. Classifier (ribosomal database program) Bayesian algorithm performs species taxonomy analysis on representative sequences of OTUs and gives statistics on the community composition of each sample at different species classification levels. Analytic diversity software Qiime (1.9.1) was used to calculate the alpha diversity indices such as Shannon and Chaol. The (Un) Weighted Unifrac analysis was used to compare whether there was a significant difference in microbial communities between samples. Based on the (Un) Weighted Unifrac sample distance matrix information, non-metric multiscale (NMDS) analysis was used to demonstrate $\beta$ diversity. Correlation analysis between species and environment (RDA) was performed using Canoco 5.0 software. We use Excel 2010, SPSS 19.0 for data statistics and analysis. 

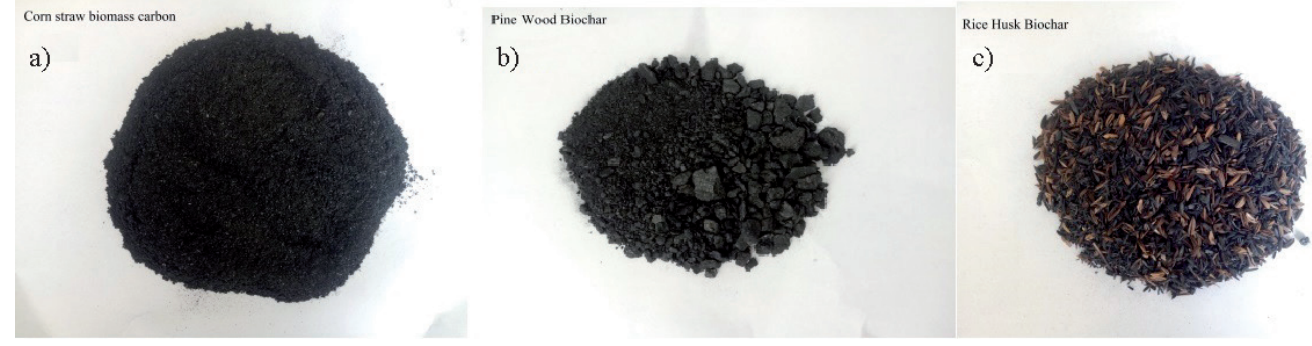

Fig. 1. Three kinds of test biomass carbon: a) corn straw biomass carbon, b) rice husk biochar, and c) pine wood biochar.

\section{Results}

The Effect of Adding Biochar on the Physicochemical Properties of Black Soil

The improving effect biomass charcoal has on black soil is beyond a doubt, as seen from Table 3. Soil $\mathrm{pH}$ after the addition of biochar showed an upward trend, of which the addition of $6 \%$ corn straw had the greatest change in $\mathrm{pH}$. The contents of total nitrogen, total phosphorus and available potassium of corn stover biomass carbon was the highest compared with other kinds of biomass carbon, which increased by $0.42 \mathrm{~g} \cdot \mathrm{kg}^{-1}, 4.32 \mathrm{~g} \cdot \mathrm{kg}^{-1}$, and $275.09 \mathrm{mg} \cdot \mathrm{kg}^{-1}$, respectively, compared with $\mathrm{CK}$ treatment. The addition of biomass carbon will inevitably lead to an increase in organic matter, of which the addition of $6 \%$ rice husk biomass carbon had the most significant effect, and the content of organic matter increased by $9.19 \mathrm{~g} \cdot \mathrm{kg}^{-1}$ compared to CK. Biomass charcoal had more significant water retention properties due to its porous surface. The moisture content of $1.2 \%$ pine biomass carbon is $19.22 \%$. The addition of biomass charcoal has little effect on the alkaline hydrolysis of nitrogen in the soil. Only the addition of $1.2 \%$ pine biomass carbon and $1.2 \%$ rice husk biomass carbon increased the content of alkaline hydrolysis nitrogen compared to $\mathrm{CK}$, and the remaining treatments decreased. Biochar has a great influence on soil available phosphorus, and its available phosphorus content increased as compared to CK treatment. Among them, the content of available phosphorus is maximal with $6 \%$ rice husk biomass carbon, and its value is $300.92 \mathrm{mg} \cdot \mathrm{kg}^{-1}$. When different amounts of the same type of biomass carbon were added, changes in the physicochemical properties of the treatments occurred. The $\mathrm{pH}$, water content, organic matter, total nitrogen, total phosphorus, available potassium, and available phosphorus in the $6.0 \% \mathrm{CB}$ treatment were all higher than that in the $1.2 \% \mathrm{CB}$ treatment, and only the alkaline hydrolysis nitrogen content was low compared to that of $1.2 \%$ CB. Between $1.2 \%$ RB and $6.0 \%$ RB treatments, $\mathrm{pH}$, water content, organic matter, total phosphorus, and available potassium, the available phosphorus content of $6.0 \% \mathrm{RB}$ were all higher than $1.2 \% \mathrm{RB}$ treatment, except total nitrogen and alkali solution. $1.2 \% \mathrm{~PB}$ and $6.0 \% \mathrm{~PB}$ treatments have the same changes in physicochemical properties as $1.2 \% \mathrm{RB}$ and $6.0 \% \mathrm{RB}$ treatments.

\section{Changes of Soil Fungal Community Abundance after the Addition of Biomass Carbon}

From Fig. 2 we can see that 5 known fungal phyla were detected from black soil, including Ascomycota, Basidiomycota, Chytridiomycota, Zygomycota, and Glomus (Glomeromycota), with Ascomycota as the predominant group, accounting for about $70.6 \%$ of the total number of OTUs, about $12.5 \%$ of Basidiomycota, about $4.5 \%$ of cystic, about $0.7 \%$ of phytotoxic, and the others. The proportion of doors is the lowest, which is barely detectable in CK and $1.2 \%$ PB treatments. The proportion of Basidiomycota in the $1.2 \% \mathrm{CB}$ treatment was significantly lower than the $6.0 \% \mathrm{CB}$ treatment, and the $1.2 \% \mathrm{~PB}$ and $6.0 \% \mathrm{~PB}$ and $\mathrm{CB}$ treatments showed similar trends. However, in the addition of rice husk biochar, the abundance of $1.2 \% \mathrm{RB}$ treatment was greater than $6.0 \% \mathrm{RB}$. However, the three phyla of Ascomycota, Zygomycota, and Glomeromycota were almost undetectable in $6.0 \% \mathrm{RB}, 1.2 \% \mathrm{~PB}$, and $6.0 \% \mathrm{~PB}$ treatments.

According to the abundance data of OUT, heat maps can aggregate different OUTs at the genus level, and heat maps can reflect the relationship between differently treated species community similarities, differences, and species clustering relationship display processing based on color gradients. A total of 67 known fungal genera were detected from 7 samples. The first 30 fungal genera with higher abundance of different treatments

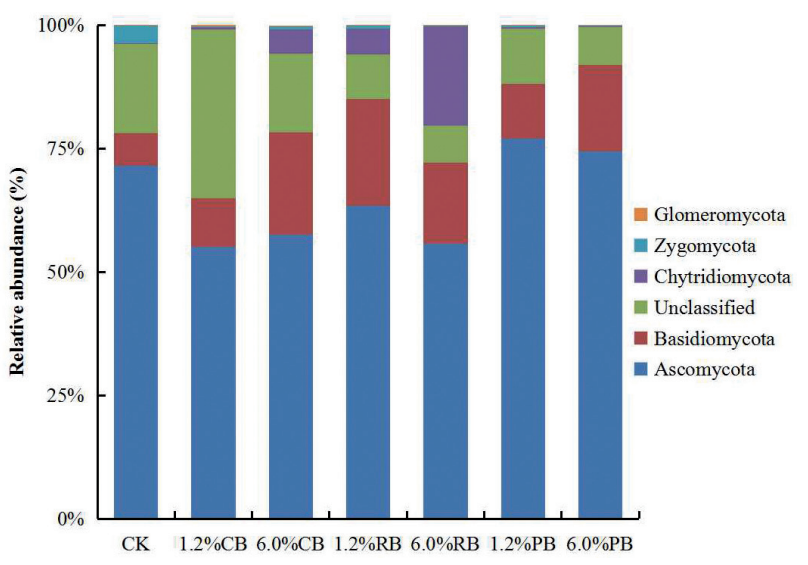

Fig. 2. Relative abundance of fungal populations in horizontal black soil. 
Table 3. Physical and chemical properties of soil after adding biomass carbon.

\begin{tabular}{|c|c|c|c|c|c|c|c|c|}
\hline Treatment & PH & $\begin{array}{c}\text { Moisture } \\
(\%)\end{array}$ & $\begin{array}{c}\text { SOM } \\
\left(\mathrm{g} \cdot \mathrm{kg}^{-1}\right)\end{array}$ & $\begin{array}{c}\text { TN } \\
\left(\mathrm{g} \cdot \mathrm{kg}^{-1}\right)\end{array}$ & $\begin{array}{c}\text { TP } \\
\left(\mathrm{g} \cdot \mathrm{kg}^{-1}\right)\end{array}$ & $\begin{array}{c}\text { AN } \\
\left(\mathrm{mg}^{-\mathrm{kg}^{-1}}\right)\end{array}$ & $\begin{array}{c}\text { AK } \\
\left(\mathrm{mg} \cdot \mathrm{kg}^{-1}\right)\end{array}$ & $\begin{array}{c}\text { AP } \\
\left(\mathrm{mg}^{\cdot} \mathrm{kg}^{-1}\right)\end{array}$ \\
\hline CK & $5.58 \pm 0.08 \mathrm{ab}$ & $13.04 \pm 1.45 \mathrm{a}$ & $37.22 \pm 5.72 \mathrm{ab}$ & $1.03 \pm 0.08 \mathrm{a}$ & $5.48 \pm 0.60 \mathrm{a}$ & $156.50 \pm 3.82 \mathrm{~d}$ & $307.77 \pm 6.19 \mathrm{~b}$ & $55.22 \pm 5.50 \mathrm{a}$ \\
\hline $1.2 \% \mathrm{CB}$ & $5.78 \pm 0.03 \mathrm{ab}$ & $11.88 \pm 2.29 \mathrm{a}$ & $37.85 \pm 8.05 \mathrm{ab}$ & $0.96 \pm 0.14 \mathrm{a}$ & $7.28 \pm 1.03 \mathrm{~b}$ & $108.29 \pm 2.19 \mathrm{~b}$ & $330.87 \pm 2.34 \mathrm{c}$ & $117.02 \pm 1.57 \mathrm{~b}$ \\
\hline $6.0 \% \mathrm{CB}$ & $6.22 \pm 0.32 \mathrm{c}$ & $15.54 \pm 2.06 \mathrm{~b}$ & $39.50 \pm 4.85 \mathrm{ab}$ & $1.45 \pm 0.18 \mathrm{~b}$ & $9.80 \pm 0.80 \mathrm{~d}$ & $98.33 \pm 6.14 \mathrm{a}$ & $582.86 \pm 11.59 \mathrm{f}$ & $195.54 \pm 2.70 \mathrm{e}$ \\
\hline $1.2 \% \mathrm{RB}$ & $5.39 \pm 0.32 \mathrm{a}$ & $16.09 \pm 0.31 \mathrm{~b}$ & $28.45 \pm 2.76 \mathrm{a}$ & $0.93 \pm 0.07 \mathrm{a}$ & $7.29 \pm 1.09 \mathrm{~b}$ & $174.85 \pm 3.29 \mathrm{e}$ & $403.94 \pm 4.81 \mathrm{~d}$ & $184.49 \pm 4.34 \mathrm{~d}$ \\
\hline $6.0 \% \mathrm{RB}$ & $5.86 \pm 0.29 \mathrm{bc}$ & $17.26 \pm 0.76 \mathrm{bc}$ & $46.41 \pm 9.98 \mathrm{~b}$ & $0.87 \pm 0.49 \mathrm{a}$ & $9.00 \pm 0.66 \mathrm{~cd}$ & $104.84 \pm 4.51 \mathrm{ab}$ & $545.26 \pm 7.63 \mathrm{e}$ & $300.92 \pm 12.33 \mathrm{f}$ \\
\hline $1.2 \% \mathrm{~PB}$ & $5.52 \pm 0.30 \mathrm{ab}$ & $19.22 \pm 0.65 \mathrm{c}$ & $29.71 \pm 0.99 \mathrm{a}$ & $1.11 \pm 0.09 \mathrm{ab}$ & $7.01 \pm 0.37 \mathrm{~b}$ & $196.60 \pm 1.67 \mathrm{f}$ & $238.72 \pm 3.70 \mathrm{a}$ & $119.98 \pm 5.24 \mathrm{~b}$ \\
\hline $6.0 \% \mathrm{~PB}$ & $5.68 \pm 0.08 \mathrm{ab}$ & $15.63 \pm 0.20 \mathrm{~b}$ & $35.66 \pm 3.26 \mathrm{ab}$ & $1.14 \pm 0.05 \mathrm{ab}$ & $7.89 \pm 0.74 \mathrm{bc}$ & $124.51 \pm 3.94 \mathrm{c}$ & $235.40 \pm 4.10 \mathrm{a}$ & $140.82 \pm 4.67 \mathrm{c}$ \\
\hline
\end{tabular}

were selected for this study. The heat map was generated using R language (Fig. 3). Among them, the dominant groups included genus Geomyces, Fusarium, Chaetomium, Penicillium, Humicola, and Trichocladium, which all belong to the same department level. Among them, $\mathrm{CK}$ and $\mathrm{RB}$ treatments had the highest abundance of genus Geomyces, $6.0 \% \mathrm{CB}$, and $1.2 \%$ PB treatment had the highest Fusarium abundance, and 1.2\% CB treatment had the abundance of Trichocladium species. $6.0 \% \mathrm{~PB}$ was the highest in Humicola. Except for the above-mentioned, several species of higher abundance were significantly concentrated in different treatments. The rest of the species also had branch similarities in different treatments.

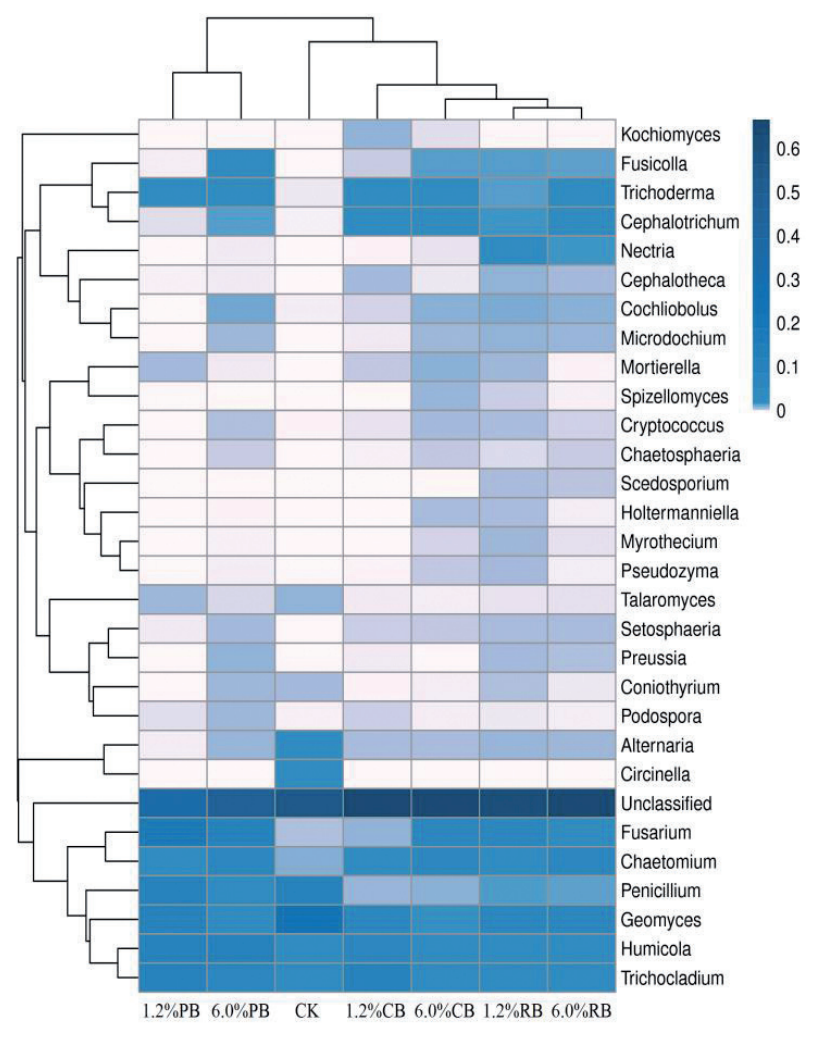

Fig. 3. Heat map of black soil fungal community level.
Diversity of Fungal Community Diversity after the Addition of Biomass Charcoal

Alpha $(\alpha)$ diversity index can reflect the richness and evenness of each treated fungal community. From Table 4 we can see that compared with CK, ACE, chaol, Shannon, and Simpson in black soil significantly increased after the addition of biomass charcoal. Therefore, the addition of biomass charcoal to black soil could increase its richness and evenness of the fungal community. Between different amounts of biomass charcoal, the ACE, chao1, Shannon, and Simpson indexes showed some differences. Treatment with $6.0 \%$ $\mathrm{CB}$ was greater than that of $1.2 \% \mathrm{CB}$, indicating that the richness of fungal communities in black soils increased with increasing corn straw biomass charcoal. The results obtained by adding pine biomass carbon and corn straw biomass carbon were the same, while the ACE, chaol, Shannon, and Simpson indexes of $6.0 \%$ RB treatments were all less than $1.2 \% \mathrm{RB}$ treatment. This means that adding more rice husk biomass carbon does not increase the richness and evenness of the fungal community.

The dilution curve used random sampling of the sequencing sequence to determine whether the sample volume is sufficient and predict species richness. From Fig. 4 we can see that when the sampling read $<10000$, with the increase of the sequencing depth, the number

Table 4. Table of black soil fungal $\alpha$ diversity index.

\begin{tabular}{|c|c|c|c|c|c|}
\hline Sample & ACE & Chaol & Shannon & Simpson & $\begin{array}{c}\text { Goods } \\
\text { coverage }\end{array}$ \\
\hline $\mathrm{CK}$ & 176.41 & 182.00 & 3.76 & 0.86 & 1.00 \\
\hline $1.2 \% \mathrm{CB}$ & 233.50 & 233.06 & 4.78 & 0.93 & 1.00 \\
\hline $6.0 \% \mathrm{CB}$ & 251.24 & 254.36 & 5.67 & 0.96 & 1.00 \\
\hline $1.2 \% \mathrm{RB}$ & 262.32 & 260.11 & 5.67 & 0.96 & 1.00 \\
\hline $6.0 \% \mathrm{RB}$ & 250.88 & 259.00 & 5.26 & 0.94 & 1.00 \\
\hline $1.2 \% \mathrm{~PB}$ & 199.40 & 214.75 & 4.01 & 0.90 & 1.00 \\
\hline $6.0 \% \mathrm{~PB}$ & 246.55 & 252.08 & 5.35 & 0.96 & 1.00 \\
\hline
\end{tabular}




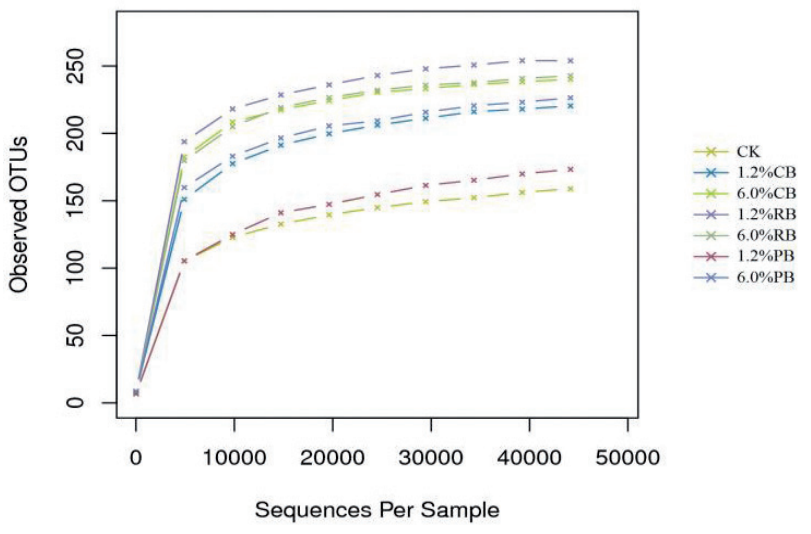

Fig. 4. Dilution curve of soil fungi in black soil.

of OUT increased rapidly. When $10000<$ read $<20000$, with the increase of the depth, the number of OUT increased slowly, when read $>20000$. As the sequencing depth increased, the number of OUTs tended to be flat, which indicated that the sequencing data at that time was more reasonable. The number of fungi was the most with $1.2 \% \mathrm{RB}$, and $\mathrm{CK}$ was the least.

Beta $(\beta)$ diversity can reflect the diversity of samples. We can see from Fig. 5 where we could observe the difference in color between $6.0 \% \mathrm{CB}$ and $6.0 \% \mathrm{RB}$ by the depth of color. The difference between the two was not significant. But there was a significant difference in color between $\mathrm{CK}$ and other treatments.

\section{Effect of Environmental Factors on Community Structure of Black Soil Fungus with Different Biochar Treatments}

In order to analyze the impact of different biomass charcoal on black soil fungal communities, a typical

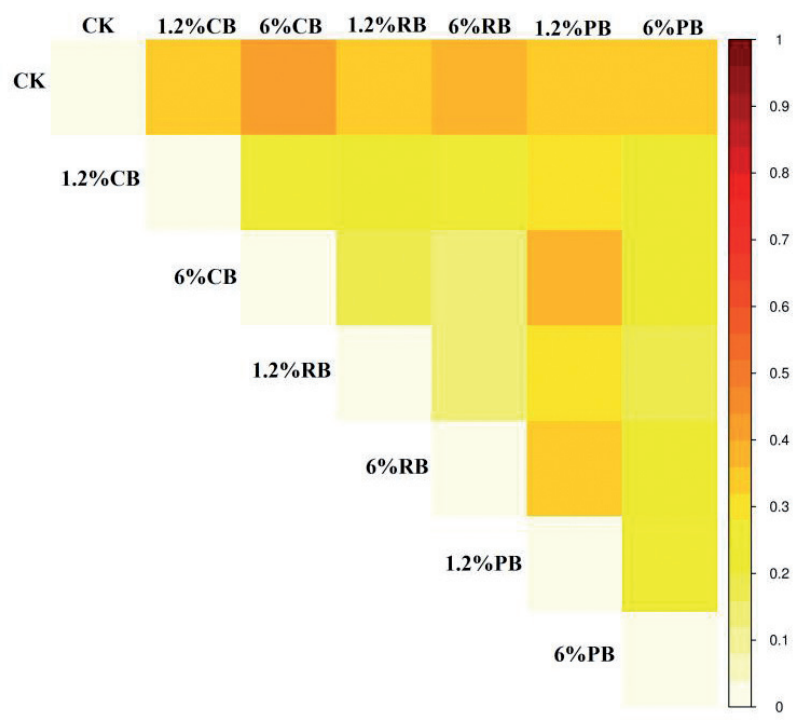

Fig. 5. Heat treatment of fungal clusters based on $\beta$-diversity analysis. correspondence analysis was performed in this study. The angles between organic matter (SOM), available potassium (AK), available phosphorus (AP), total phosphorus (T-P), and $\mathrm{pH}$ vector arrows were acute (Fig. 6), indicating that there is a synergy between the five physical and chemical factors. The correlation between $1.2 \% \mathrm{CB}$ and organic matter (SOM) was higher, $1.2 \% \mathrm{RB}$ and $6.0 \% \mathrm{RB}$ were more correlated with available potassium (AK), and $6.0 \% \mathrm{CB}$ was more correlated to available phosphorus (AP). The correlation between $6.0 \% \mathrm{~PB}$ with moisture content (MOC) was higher, and the correlation between $1.2 \% \mathrm{~PB}$ and alkaline dissolved nitrogen (AN) was higher. The correlations between the genus Cephalotheca, Nectria, Cephalotrichum and Microdochium and 1.2\% CB, 1.2\% $\mathrm{RB}, 6.0 \% \mathrm{RB}$ and $6.0 \% \mathrm{CB}$ were the highest, and the correlations between the genus Fusarium and Humicola and $6.0 \% \mathrm{~PB}$ were the highest.

\section{Discussion}

\section{The Effect of Adding Biomass Carbon on the Physical and Chemical Properties of Black Soil}

Liang Feng et al. [19] found that after applying biomass carbon in calcareous soil, the $\mathrm{PH}$, available potassium and water content in the soil increased after two years, Lehmann et al. [20] also found that the application of biomass charcoal can improve the physicochemical properties of soil. Huang Chao et al. [21] used a potted experimental graduate student material charcoal to improve the properties of red soil and found that the addition of biomass charcoal can increase soil $\mathrm{pH}$, water-holding capacity, available phosphorus, available potassium, and alkali-hydrolyzed nitrogen, and improve plant growth. The results of this study are the same as those of the above studies. After the addition of biomass carbon in black soil, the contents of $\mathrm{pH}$, organic matter, water content, available phosphorus, available potassium, and total phosphorus in black soil increased compared with CK. Adding different amounts and types of biomass carbon has little effect on the physical and chemical properties of the soil, but some rules are also obtained from the data. The moisture content, organic matter, total phosphorus, available potassium, and available phosphorus content of $6.0 \%$ of biomass carbon added to the whole weight are significantly higher than that of $1.2 \%$ of total weight, and the total nitrogen and alkaline nitrogen are just the opposite. In the different types of biomass charcoal, the physicochemical properties of corn straw biomass charcoal and rice husk biomass charcoal are generally higher than pine biomass carbon. Therefore, the improvement effect of corn straw biomass charcoal and rice husk straw biomass charcoal are better than pine biomass charcoal. 


\section{The Effect of Adding Biomass Carbon on Fungal Communities}

The influence of the addition of biomass charcoal on soil microbes has been a cause of concern for many people [22]. Lehmann et al. [23] found that the microbial biomass of Amazon black charcoal increased due to the enrichment of biomass charcoal, and the microbial composition and enzyme activity changed, but the fungal diversity did not change much. This may be because the Amazon black soil carbon has naturally existed for many years, and because its carbon content is too high, the concentration is too great to affect the activity of fungi in the soil. Hu et al. [24] found that in red soils, the addition of biomass charcoal can increase bacterial diversity in a short period of time, while fungal diversity decreases. This may be because the red soil is an acidic soil, and after the addition of biomass charcoal, the $\mathrm{pH}$ of the soil is increased, and fungi prefer acidic soils. Bacteria prefer neutral soils, so the bacterial diversity increases, but the fungal diversity does not change. Reis [25] and Qin et al. [26] also found that the addition of biomass charcoal has no significant effect on the alpha diversity of fungi. And He Yuting et al [27] added tobacco stem and mulberry biomass carbon to red soil and found that the number of fungi, actinomycetes, and bacteria in red soil increased significantly. The results of this study are the same as those of He Yuting et al. The three biomass carbons added in the black soil increased the number of soil fungi and fungal diversity. We detected a total of 5 fungal phyla and 67 fungal genera in black soil. The dominant genus includes Geomyces, Fusarium, Chaetomium, and Penicillium, and the fungal diversity of Humicola was significantly higher in treatments with biomass carbon than that

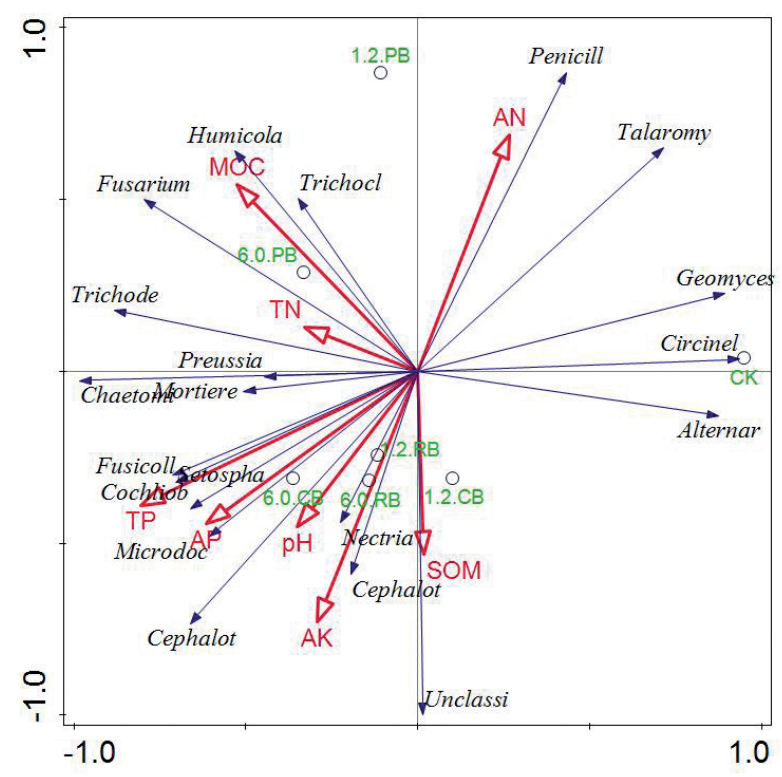

Fig. 6. RDA analysis between environmental factors and fungal genera levels. of CK treatment. Adding the same type but different amounts of biomass charcoal treatment resulted in different abundance fungi communities. For example, the abundance of OUT of Ascomycota, Basidiomycota, Chytridiomycota, Zygomycota, and Glomeromycota with $6.0 \%$ of $\mathrm{CB}$ treatment was significantly higher than that of $1.2 \%$ CB treatment. There were three dominant genera of Fusarium, Chaetomium, and Penicillium when black soil was treated with $6.0 \%$ CB. Species above $1.2 \%$ CB treatment, the diversity index showed the same trend. In the addition of rice husk biochar treatment, only $6.0 \%$ of the RB treated Chytridiomycota was higher than the $1.2 \%$ RB treatment, and the other fungal gate was $1.2 \%$. The abundance of RB was higher and the dominant genus was higher. Only Chaetomium (Chaetomium) is treated above $1.2 \% \mathrm{RB}$, and the diversity index is the opposite of the treatment with corn straw biomass carbon. In the treatment of adding pine biomass carbon, the abundance of $6.0 \%$ PB-treated Basidiomycota, Chytridiomycota, and Glomeromycota was higher than that of $1.2 \%$ PB treatment. The dominant species is only Chaetomium (1.2\% PB), and the diversity index is the same as that of corn straw biomass carbon treatment. From the influence of environmental factors on the fungal community structure (Fig. 6), it can be seen that the impact of biomass charcoal on fungal communities is not direct, but that of the fungal community diversity is indirectly affected by changing the physical and chemical properties of the soil.

\section{Conclusions}

Because of its excellent characteristics, biomass charcoal can change the physicochemical properties of soil. This study shows that after adding biomass charcoal, the water content of black soil increases significantly, and the water content is critical to the growth of the crop. The optimization of soil physical and chemical properties can also promote the change of soil microbial communities. The abundance of fungi and increase of fungal diversity in soils with biomass charcoal and the influence of environmental factors on fungal communities can be derived. The physical and chemical properties of the soil and the improvement of the soil can increase the abundance and diversity of the fungus, which interacts with each other and does not play a single role. Therefore, the addition of biomass carbon can not only change the physical and chemical properties of the soil, but also increase the diversity of soil fungi, and plays a key role in the maintenance of soil ecosystems.

\section{Acknowledgements}

We would like to thank the Jilin Province Natural Fund (20170101077JC), the National key R\&D project sub-project (2017YFD0300405--4), the Jilin 
Province Science and Technology Development Plan (20160307006NY), and the Natural Science Foundation of Jilin province, China (Subject to guide project, No. 20170101004JC) for assistance in this research.

\section{Conflict of Interest}

The authors declare no conflict of interest.

\section{References}

1. WEBER K., QUICKER P. Properties of biochar. Fuel, 217, 240, 2018.

2. WU M., HAN X., ZHONG T., YUAN M., WU W. Soil organic carbon content affects the stability of biochar in paddy soil. Agriculture Ecosystems \& Environment, 223, $59,2016$.

3. CANTRELL K.B., HUNT P.G., UCHIMIYA M., NOVAK J.M., RO K.S. Impact of pyrolysis temperature and manure source on physicochemical characteristics of biochar. Bioresource Technology, 107 (2), 419, 2012.

4. ZWIETEN L.V., KIMBER S., MORRIS S., CHAN K.Y., DOWNIE A., RUST J., JOSEPH S., COWIE A. Effects of biochar from slow pyrolysis of papermill waste on agronomic performance and soil fertility. Plant \& Soil, 327 (1/2), 235, 2010.

5. ZHANG Q.Z., WANG X.H., DU Z.L., LIU X.R., WANG Y.D. Impact of biochar on nitrate accumulation in an alkaline soil. Soil Research, 51 (6), 521, 2013.

6. MUKHERJEE A., LAL R. Biochar impacts on soil physical properties and greenhouse gas emissions. Agronomy, 3 (2), 313, 2013.

7. SUN D., MENG J., LIANG H., YANG E., HUANG Y., CHEN W., JIANG L., LAN Y., ZHANG W., GAO J. Effect of volatile organic compounds absorbed to fresh biochar on survival of bacillus mucilaginosus, and structure of soil microbial communities. Journal of Soils \& Sediments, 15 (2), 271, 2015.

8. STEINER C., GLASER B., TEIXEIRA W.G., LEHMANN J., BLUM W.E.H., ZECH W. Nitrogen retention and plant uptake on a highly weathered central amazonian ferralsol amended with compost and charcoal.Journal of Plant Nutrition and Soil Science $=$ Zeitschrift fuer Pflanzenernaehrung und Bodenkunde, 171 (6), 893, 2010.

9. RILLIG M.C., MUMMEY D.L. Mycorrhizas and soil structure. New Phytologist, 171 (1), 41, 2010.

10. MEHARI Z.H., ELAD Y., RAV-DAVID D., GRABER E.R., HAREL Y.M. Induced systemic resistance in tomato (solanum lycopersicum) against botrytis cinerea, by biochar amendment involves jasmonic acid signaling. Plant \& Soil, 395 (1-2), 31, 2015.

11. MENDES L.W., BROSSI M.J.D.L., KURAMAE E.E., TSAI S.M. Land-use system shapes soil bacterial communities in southeastern amazon region. Applied Soil Ecology, 95, 151, 2015.

12. ISHII T., KADOYA K. Effects of charcoal as a soil conditioner on citrus growth and vesicular-arbuscular mycorrhizal development. Journal of the Japanese Society for Horticultural Science, 63 (3), 529, 1994.
13. YU J., DEEM L.M., CROW S.E., DEENIK J.L., PENTON C.R. Biochar application influences microbial assemblage complexity and composition due to soil and bioenergy crop type interactions. Soil Biology \& Biochemistry, 117, 97, 2018.

14. TONG H., HU M., LI F.B., LIU C.S., CHEN M.J. Biochar enhances the microbial and chemical transformation of pentachlorophenol in paddy soil. Soil Biology \& Biochemistry, 70 (2), 142, 2014.

15. KRIEG T., SYDOW A., SCHRÖDER U., SCHRADER J., HOLTMANN D. Reactor concepts for bioelectrochemical syntheses and energy conversion. Trends in Biotechnology, 32 (12), 645, 2014.

16. SINGH B., FANG Y., COWIE B.C.C., THOMSEN L. Nexafs and xps characterisation of carbon functional groups of fresh and aged biochars. Organic Geochemistry, 77 (22), 1, 2014.

17. LEHMANN J., JOSEPH S. Biochar for Environmental Management, $2^{\text {nd }}$ Edition, 2015.

18. BROOKES P.C., LANDMAN A., PRUDEN G., JENKINSON D.S. Chloroform fumigation and the release of soil nitrogen: a rapid direct extraction method to measure microbial biomass nitrogen in soil. Soil Biology and Biochemistry, 17 (6), 837, 1985.

19. LIANG FENG, GUI-TONG, QI-MEI, ZHAO XIAORONG. Crop yield and soil properties in the first 3 years after biochar application to a calcareous soil. Journal of Integrative Agriculture, 13 (3), 525, 2014.

20. LEHMANN J., JOSEPH S. Biochar for environmental management: an introduction. In: Lehmann, J., Joseph, S. (Eds.), Biochar for Environmental Management: Science and Technology. Earthscan, London, 1, 2009.

21. HUANGCHAO, LIULIJUN, ZHANGMINGKUI Effect of Biochar on Red Soil Properties and Growth of Ryegrass [J] Journal of Zhejiang University (Agricultural and Life Sciences Edition) 37 (4), 439, 2011.

22. FOEREID B. Biochar in nutrient recycling - the effect and its use in wastewater treatment. Open Journal of Soil Science, 05 (2), 39, 2015.

23. LEHMANN J., RILLIG M.C., THIES J., MASIELLO C.A., HOCKADAY W.C., CROWLEY D. Biochar effects on soil biota - a review.Soil Biology \& Biochemistry, 43 (9), 1812, 2011.

24. HU L., CAO L., ZHANG R. Bacterial and fungal taxon changes in soil microbial community composition induced by short-term biochar amendment in red oxidized loam soil. World Journal of Microbiology \& Biotechnology, 30 (3), 1085, 2014

25. REIS L.A., FABIANA D.S.C., WURDIG R.L.F., MUI T.S., EURYA K.E. Fungal community assembly in the amazonian dark earth:.Microbial Ecology, 71 (4), 962, 2016.

26. YAO Q., LIU J., YU Z., LI Y., JIN J., LIU X., WANG G. Three years of biochar amendment alters soil physiochemical properties and fungal community composition in a black soil of northeast china. Soil Biology \& Biochemistry, 110, 56, 2017.

27. HEYUTING, WANGCHANGQUAN, SHENJIE, LIBIN, LIBING, CHENLIN, PANXINGBING. Effects of Two Kinds of Biochar on Structure Stability and Microbial Communities of Aggregates in Red Soil [J]. Chinese Agricultural Sciences, 49 (12), 2333, 2016. 